\title{
INTEGRASI ILMU KEISLAMAN DAN FILSAFAT: PERSPEKTIF FILSAFAT ILMU
}

\author{
Wardani \\ Universitas Islam Negeri Antasari Banjarmasin \\ mwardanibjm@gmail.com
}

Diterima 15 Juni 2019 | Direview 20 Juni 2019| Diterbitkan 30 Juni 2019

\begin{abstract}
:
This article intends to examine the integration between Islamic studies and philosophy from the philosophy of science perspective. The focus of this study primarily focuses on Islamic studies in Islamic university in Indonesia, regarding the real conditions of its science seen from the perspective of philosophical learning. The second focus is the offer of the philosophy of science approach in developing Islamic studies. The article concludes that Islamic studies at the university are "poor of philosophy" because the direction of the study is mostly dominated by normative studies. Therefore, as the first step, the bachelor degree in all faculties of Islamic university should study philosophy of science, it is also necessary to develop Islamic studies from the philosophy of science perspective, such as the philosophy proposed by Thomas Kubn and Imre Lakatos.
\end{abstract}

Keywords: philosophy of science, integration of science, Islamic studies.

\begin{abstract}
Abstrak:
Artikel ini bertujuan mengkaji tentang bagaimana integrasi antara ilmu-ilmu keislaman dengan filsafat ditinjau dari perspektif filsafat ilmu. Fokus kajian ini terutama ditujukan pada pengkajian Islam di perguruan tinggi keagamaan Islam di Indonesia tentang kondisi riil keilmuanny dilihat dari perspektif pembelajaran filsafat. Fokus kedua adalah tawaran pendekatan filsafat ilmu dalam pengembangan kajian Islam. Artikel berkesimpulan bahwa kajian Islam di perguruan "miskin filsafat", karena arah kajian lebih banyak didominasi oleh hanya kajian normatif. Atas dasar ini, sebagai langkah awal filsafat ilmu perlu dipelajari di strata satu perguruabn tinggu di semua fakultas. Begitu juga, perlu pengembangan kajian-kajian Islam dari perspektif filsafat ilmu, seperti usulan filsafat Thomas Kubn dan Imre Lakatos.
\end{abstract}

Kata-kunci: filsafat ilmu, integrasi ilmu, kajian Islam.

\section{Pendahuluan}

Menurut Alvin Toffler dalam Future Shock setiap masyarakat mempunyai sikap yang karasteristik pandangannya terdapat pada tiga dimensi waktu, masa lampau, masa kini dan masa depan. Inilah yang memungkinkan terjadinya apa yang disebut Toffler sebagai "biaswaktu" (time-bias) yang terbentuk sebagai tanggapan terhadap laju perubahan. Bias waktu, menurutnya, merupakan determinan yang paling tidak kentara, namun paling menentukan dalam membentuk tingkah laku masyarakat. Hal ini tercemin dalam cara masyarakat mempersiapkan generasi mudanya memasuki abad kontemporer. ${ }^{1}$

Dalam sejarahnya, Amerika ternyata telah terjebak dalam bias waktu dalam sistem pendidikannya. Sebuah upaya "progresif' telah dilakukan John Dewey untuk mengubah bias waktu yang lama. Ia bergulat melawan orientasi pendidikan tradisional ke masa lampau dan mencoba mengubah fokus pendidikan pada sasaran sekarang dan di sini (here and now). Katanya, "Jalan keluar dari sistem skolastik yang menganggap masa lampau itu sebagai sarana untuk memahami masa kini”. Namun, beberapa dasawarsa kemudian kalangan tradisionalis, seperti Jacques Maritiain dan kalangan neo-Aristoteles, seperti Robert Hutchins, mengcounter upaya penyeimbangan ke arah masa kini. Hutchins, mantan presiden Universitas Chicago dan kepala Center for the Study of Democratic Institutions, menuduh para pendidik yang mengorientasikan muridnya ke arah perkembangan kontemporer, sebagai anggota "kultus terburu-buru". Kaum progresif dicap melakukan kejahatan pengecut: "paham kekinian" (presentism).

Realitas sejarah yang sama, sebagaimana dituturkan oleh Alvin Toffler tersebut, kita temukan pula dalam sejarah Islam abad pertengahan, ketika terjadi stagnasi pemikiran

\footnotetext{
${ }^{1}$ Alvin Toffler, Future Shock, ter. Sri Koesdiyatnah (Jakarta: Panjta Simpati, 1992), h. 356.

${ }^{2}$ Toffler, Future Shock, h. 368.
} 
keislaman (diawali dengan runtuhnya kota peradaban Islam, Bagdad, pada tahun $1258 \mathrm{M}$ ). Salah satu proses regressif sejarah intelektual Islam yang sangat mencolok adalah pelabelan ilmu-ilmu rasional (al-'ulum al-'aqlìah), seperti filsafat dengan segala cabangnya (logika/manthiq, metafisika spekulatif/ theologi filosofis dan sebagainya) sebagai "ilmu-ilmu luar atau selundupan" (al-ulùm al-khârijìyah), sebuah penyebutan yang mendeskreditkan filsafat sebagai ilmu yang pada masa al-Makmum pada masa penerjemahan karya-karya intelektual filsuf Yunani dianggap sangat penting. Dampak dari sikap ortodoks skolastisisme Islam pada abad pertengahan tersebut ternyata berakibat pada tercerabutnya - meski tidak secara totalitas - akar-akar rasionalitas pemikiran Islam. "Trauma Islam" masa lalu tersebut mengkristal pada pola pemikiran keislaman tentang bagaimana seharusnya pendidikan di institusi Islam dilakukan. Sebagai konsekuensi logisnya, pola pemikiran intelektual di kalangan umat Islam secara umumnya tampak "terasingkan" (alienated) - meminjam istilah filosofis Karl Marx - dari rasionalitas. Jika pun harus dikatakan bahwa struktur bangunan pemikiran Islam banyak mendasarkan diri atas argumen-argumen filosofis Yunani, maka ideide filsafat Stoa yang lebih tampak dibanding ide-ide Aristoteles, demikian Josep van Ess dalam The Logical Structure of Islamic Theology. ${ }^{4}$ Ide-ide Stoic hidup secara subur dan memperoleh tempat luas dalam sikap asketisme dengan proses justifikasi teks-teks suci.

Model penyelenggaraan pendidikan tinggi secara umum dan pendidikan tinggi Islam semisal perguruan tinggi keagamaan Islam secara khusus, agaknya, menurut penulis, masih belum bisa melepaskan diri kungkungan pola pikir tersebut. Jika di kalangan akademisi Amerika, dalam deskripsi Alfvin Toffler di atas, dahulu dan, menurut penulis, berlanjut hingga sekarang, ada sikap resistensi terhadap modernisasi dunia pendidikan, maka di kalangan akademisi pendidikan tinggi Islam resistensi yang sama terhadap modernisasi pendidikan justru lebih menyedihkan, karena dijustifikasi oleh alasan-alasan normatif agama. Filsafat menjadi "terpinggirkan" (marginalisasi) dalam beberapa waktu lamanya dari porsi perhatian akademisi (mahasiswa dan dosen) pendidikan tinggi Islam, kecuali dalam perkembangan belakangan. Dalam konteks tersebut, seharusnya disadari asumsi, sebagaimana dikemukakan oleh Jaroslav Pelikan dalam The Idea of University: A Reexamination, bahwa "sebuah masyarakat modern tak mungkin dapat dipahami tanpa peran universitas" ( $a$ modern society is unthinkable without the university). ${ }^{5}$ Masyarakat yang modern dengan segala kompleksitas permasalahannya, baik politis, realigius, sosiologis, antropologis, ekonomis dan sebagainya, hanya dapat dipahami dan dicarikan solusinya secara akademis melalui institusi pendidikan, terutama pendidikan tinggi, yang menyediakan perangkat metodologis keilmuan. Logikanya adalah bahwa pendidikan tinggi harus juga mengalami modernisasi, dengan mengadopsi komponen keilmuan filsafat sebagai mata kuliah yang dipelajari. Selama ini, pendidikan tinggi kurang mengembangkan komponen matakuliah keilmuan yang memungkinkan tumbuhnya berpikir kritis, analitis, metodologis dan mandiri, sehingga eksistensi pendidikan tinggi menjadi dipertanyakan. Judul buku-buku yang terbit di Barat,

${ }^{3}$ Lihat Oliver Leamen, An Introduction to Medieval Islamic Philosophy, (London dan Cambridge University Press, 1985), terutama bagian I tentang perdebatan sekitar isu-isu metafisis spekulatif filosofis antara al-Ghazâlî (yang mewakili kalangan fuqaha ortodoks) dan Ibn Rusyd (kalangan filsuf Islam rasional); juga Mohammed Arkoun, Nalar Islami dan Nalar Modern: Berbagai Tantangan dan Jalan Baru, terj. Rahayu S. Hidayat (Jakarta: INIS, 1994). Tentang persentuhan ilmu keislaman dengan pemikiran Yunani, lihat William Montgomery Watt, Islamic Theology and Theology: an Extended Survey (Edinburgh: Endiburgh University Press, 1992), h. 133.

4Josep van Ess, "The Logical Structure of Islamic Theology”, dalam An Anthology of Islamic Studies, ed. Issa J. Boullata (Montreal: McGill - Indonesia IAIN Development Project, 1992), h. 50. Menurut Van Ess, "Aristoteles tidak pernah bisa secara sempurna menundukkan filsafat Stoa dalam Islam" (Aristotle never vanquishes completely the Stoics in Islam).

5Jaroslav Pelikan, The Idea of University: A Reexamination, (New Heaven: Yale University Press, 1992), $\mathrm{h}$. 13. 
seperti tampak dari karya Allan Bloom, ${ }^{6}$ Roger Kimbal, ${ }^{7}$ Diane Ravith, ${ }^{8}$ Theodore Ziolkowski, ${ }^{9}$ dan Bruce Wilshire ${ }^{10}$ menggambarkan tentang krisis yang terjadi di perguruan tinggi.

Kesenjangan yang mencolok dan gap yang dalam antara ada ada (is) dan yang seharusnya (ought) dalam wacana keilmuan pendidikan tinggi mengandaikan diterapkannya filsafat sebagai basis kritisisme dalam kerangka berpikir akademik Islam. Salah satu cabang ilmu filsafat yang paling penting adalah cabang filsafat yang sudah lama dikenal dan dikembangkan di dunia Barat sejak abad ke-18, yaitu filsafat ilmu (philosophy of science, wissenchafilehr, atau wetenschapspleer).

\section{Integrasi Ilmu dari Perspektif Filsafat Ilmu: Apa dan Mengapa}

Interaksi Filsafat dan Ilmu. Sejarah pemikiran filsafat Yunani menunjukkan integritas filsafat dan ilmu. Bagi Aritoteles, sophia adalah pengetahuan tertinggi dan philosophia adalah sinonim dengan episteme dalam pengertian sebagai bangun pengetahuan rasional dengan obyek tertentu. Aristoteles mengklasifikasikan pengetahuan rasional manusia kepada tiga; (1) praktike, (2) poietike dan (3) theoretike. ${ }^{11}$

Pada akhir abad ke-18, fisika masih disebut sebagai "ilmu alam". Akan tetapi, pada pertengahan abad ke-19 fisika, kimia dan biologi secara umum dianggap sebagai imu-ilmu alam di banding sebagai cabang-cabang filsafat alam. Pada abad ke-20, Henry Aiken menunjukkan bahwa filsafat melahirkan logika formal linguistik dan teori tanda sebagai disiplin yang hampir berdiri sendiri. Akhirnya, berkembanglah disiplin-disiplin ilmu lain yang berdiri sendiri dari filsafat, seperti biologi, psikologi, ilmu sosial dan sebagainya. Akan tetapi, menurut Prof. Jose Ferrater Mora, ${ }^{12}$ dalam kondisi tersebut tetap ada interrelasi filsafat dan ilmu. Perkembangan ilmu teoretis selalu menjadi relevan bagi suatu telaah filosofis dan perubahan besar dalam bentuk apa pun hasil atau metode ilmu merupakan refleksi dari perkembangan filsafat. Dengan demikian, ilmu merupakan persoalan permanen filsafat.

Interaksi yang terjadi antara filsafat ilmu menjadi ilmu lebih filosofis dan menjadi filsafat lebih ilmiah. Hasil dari interaksi antara keduanya termanifestasi dalam filsafat ilmu, sebagaimana dikemukakan oleh Arthur Pap,

On the one hand, scientists have become more "philosophical" owing to conceptual or methological difficulties: conceptual difficulties mainly in recent quantum physics, methological difficulties mainly in psychology and the social sciences. On the other hand, the rise of analytic philosophy more reputable in the eyes of scientists who used to be repelled by its impressionistic vegueness and metaphysical speculations.

Dari kutipan di atas, tampak usulan agar ada interaksi antara ilmu dan filsafat. Para ilmuwan menghadapi persoalan serius, yaitu pada tingkat konseptual atau metodologis. Ilmu apa pun

${ }^{6}$ Allan Bloom, The Closing of the American Mind: How Higher Education Has Failed Democracy and Impoverished the Shouls of Today's Students, (New York: Simon and Schuster Inc., 1987).

${ }^{7}$ Roger Kimbal, Tenured Radicals: How Politics Has Corrupted Our Higher Education, (Chocago: Ivan R. Dee, 1990). Terbit juga pada 2008. Postscript buku ini bisa dilihat dalam https://www.newcriterion.com/issues/1991/1/aoetenured-radicalsa-a-postscript (4 Juni 2019).

${ }^{8}$ Diane Ravith, The Schools We Deserve: Reflections on the Educational Crises of Our Time (USA: Basic Books, 1987). $177-195$

9Theodore Ziolskwi, “The Ph.D. Squid," dalam The American Scholar, Vol. 59, No. 2 (Spring 1990), h.

${ }^{10}$ Bruce Wilshire. The Moral Collapse of the University: Professionalism, Purity, and Alienation (New York: Suny, 1990).

${ }^{11}$ The Liang Gie, Philosophy As An Element or Human Existence; A Systematic Clarification, (Yogyakarta: PUBIB, 1998), h. 151.

12The Liang Gie, Philosophy, h. 152-153.

${ }^{13}$ The Liang Gie, Philosophy, h. 157. 
tentu tidak akan terlepas dari prinsip metodologisnya yang dengan begitu bisa dinilai keilmiahan sebuah riset. Contoh yang dikemukakan oleh Arthur Pap adalah fisika quantum, psikologi dan ilmu-ilmu sosial. Dalam ilmu-ilmu sosial, misalnya, riset-riset yang dilakukan harus diikat dengan perspektif yang secara filosofis bisa dianggap valid, seperti, melalui paradigma-paradigma (posivistik, fenomenologis, fakta sosial, tindakan sosial dan sebagainya. Di sisi lain, filsafat bisa juga dianggap memiliki kekurangan, misalnya, bisa dianggap terjebak pada spekulasi metafisis, sehingga, misalnya, dalam argumen tentang adanya Tuhan dalam metafisika bisa ditopang oleh berbagai teori ilmu pengetahuan, seperti teori Big Bang.

Dari Filsafat Pengetabuan ke Filsafat Ilmu. Menurut Plato, pengetahuan sejati adalah apa yang disebutnya sebagai episteme, yaitu pengetahuan yang tunggal dan tak berubah sesuai dengan ide-ide abadi. Ingatan dan intuisi ideanya Plato diganti oleh Aristoteles dengan abstraksi. Menurutnya, pengetahuan merupakan hasil kegiatan manusia yang mengamati kenyataan yang banyak dan berubah, lalu melepaskan unsur-unsur "universal" dari yang "praktukular". Dengan abstraksi tersebut, manusia bergerak dari wilayah inderawi melalui taraf dugaan dan pendapat hingga mencapai episteme sebagai pengetahuan sejati. Dalam episteme, manusia tak hanya mengetahui "tentang" (Yunani: "boti"; Latin: "propter qoud") terjadinya sesuatu. Dengan demikian, pengetahuan dicapai melalui "sebab-musabab atau kausalitas" (Latin: "cognitio percausas") dalam lingkupnya yang luas, baik sebab formal (formal cause), sebab material (material cause), sebab efisien (efficient cause), maupun sebab final (final cause). ${ }^{14}$

Dasar pemikiran Plato dan Aristoteles tentang epirisme tersebut menjadi alur pemikiran filosofis tentang hakikat ilmu sekarang. Dengan kombinasi pelbagai elemen, pemikiran, atau proses, seperti kombinasi nalar model deduktif dan induktif, elemen masalah atau problem, proses reduksi data kepada interpretasi, penyaringan, obyektivitasi, maka secara subtansi ilmu atau pengetahuan ilmiah adalah pengetahuan yang didasarkan kerja metodologis. Dengan demikian, ilmu adalah pengetahuan yang ilmiah. Atas dasar ini, fase perkembangan evolutif pengetahuan manusia sebenarnya, menurut grand theory Auguste Comte misalnya, bergerak dari fase pengetahuan yang non-ilmiah atau pra-ilmiah menuju pengetahuan ilmiah, karena tolak ukur keilmiahan pengetahuan didasarkan atas sifat empiris, terindera, terukur, didasarkan atas asas-asas berpikir ilmiah dan dapat diulang dibuktikan (diverifikasi) atau dapat dibuktikan keliru (uji falsifikasi). Oleh karena itu, keyakinan mitologis (teogoni dan kosmogoni) dalam alam pemikiran klasik Yunani tidak dikategorikan sebagai ilmu, karena tidak didasarkan atas metode ilmiah.

Dengan pembedaan (distingsi) antara pengetahuan dan ilmu, dapat dibuat pembedaan antara filsafat pengetahuan dan filsafat ilmu. Menurut C. Verhaak, ${ }^{15}$ filsafat pengetahuan menghubungkan sebab-musabab dengan bertitik tolak pada gejala pengetahuan dalam kehidupan sehari-hari. Filsafat pengetahuan mempersoalkan "kebenaran", "kepastian" dan tahap-tahapnya, "objektivitas", "abstraksi", "intuisi" dan pertanyaan mengenai "dari mana asalnya dan kemanakah arah pengetahuan". Filsafat ilmu tidak hanya membicarakan obyekobyek tersebut sebagai "gejala pengetahuan secara umum. Akan tetapi, sifat teratur dan sistematis yang terdapat pada ilmu pengetahuan sehingga dapat dipertanggungjawabkan secara teoritis dan reflektif menuntut pembahasan secara filosofis dalam bentuk filsafat ilmu pengetahuan. Dengan kata lain, metode ilmiahlah yang menjadi ciri ilmu.

Beerling, Kwee Mooij dan Van Peursen dalam Inleiding tot de Weteshasleer ${ }^{16}$ membedakan filsafat ilmu ke dalam dua wilayah. Pertama, filsafat ilmu dalam arti luas yang

\footnotetext{
${ }^{14}$ Verhaak dan R. Haryono Imam, Filsafat Ilmu Pengetahuan (Jakarta: Gramedia, 1997), 10-11.

${ }^{15}$ Verhaak dan R. Haryono Imam, Filsafat Ilmu Pengetabuan, 12-13

${ }^{16}$ Beerling, Kwee Mooij dan Van Peursen dalam Inleiding tot de Weteshasleer, terj. Soejono Soemargono (Yogyakarta: Tiara Wacana, 1990), h. 3-4.
} 
menampung permasalahan yang menyangkut hubungan-hubungan ke luar dari kegiatan ilmiah, seperti implikasi-implikasi ontologik-metafisik dari citra dunia yang bersifat ilmiah, dimensi aksiologis-etis penerapan ilmu, konsekuensi-konsekuensi pragmatik-etis, penyelenggara ilmu dan sebagainya.

Kedua, filsafat ilmu dalam arti sempit, yang membicarakan kategori-kategori serta metode-metode yang digunakan dalam ilmu-ilmu tertentu atau dalam kelompok ilmu-ilmu tertentu, seperti kelompok ilmu-ilmu alam (natural science), kelommpok ilmu teknis dan sebagainya. Filsafat ilmu-ilmu sosial sendiri berkembang dalam tiga ragam, yaitu: metaideologi, metafistik dan metodologi disiplin ilmu. Arti meta telah mengalami perkembang dari yang transenden (spekulatif) ke teorinya teori (positivistik) dan sekarang berkembang ke etik (metafistik). Dalam arti normatif-moral (spekulatis), filsafat ilmu berkembang ke etik obyektif universal (realisme). ${ }^{17}$

Filsafat ilmu berkembang dengan dua fungsi, yaitu sebagai teori konfirmatif (confirmatory theories) dan teori penjelasan (theories of explanation). Yang pertama berupaya mendeskripsikan relasi normatif antara hepotesis dan bukti (evidensi). Yang kedua berupaya menjelaskan berbagai fenomena kecil atau besar secara sederhana.

Filsafat yang mengkaji aspek epistemologi (filsafat pengetahuan) secara spesifik mengkaji hakikat ilmu (pengetahuan ilmiah). Wilayah yang menjadi telaah filosofis tentang ilmu menyentuh tiga domain: pertama, domain ontologis ilmu yang mengajukan pertanyaanpertanyaan filosofis berikut: obyek apa yang telah ditelaah ilmu? Bagaimana wujud hakiki dari obyek tersebut? Bagaimana relasi obyek dengan daya tangkap manusia (seperti berpikir, merasa dan mengindera) yang menghasilkan ilmu pengetahuan?

Kedua, domain epistemologis. D.W. Hamlyn mendefinisikan epistemologi sebagai cabang filsafat yang concern dengan hakikat dan skop pengetahuan, asumsi dan dasarnya, serta reliabilitas pengetahuan. ${ }^{18}$ Epistemologi mencoba mengavaluasi secara kritis ide common sense bahwa kita sering (atau selalu) memperoleh pengetahuan secara rasional dengan dijustifikasi oleh dasar keyakinan yang dimiliki. Beberapa filsuf berupaya mempertahankan ide common sense tersebut dengan argumen-argumen filosofis. Filsuf yang lain justru menempatkan posisi penolakan tegas terhadap ide commensense. Filsuf yang mengklaim tentang tidak mungkinnya memperoleh pengetahuan, atau bahwa keyakinan kita tak dapat dibenarkan secara rasional, mempertahankan sikap philosophical scepticism (skeptisisme filosofis). ${ }^{19}$ Etiene Gilson, misalnya, beranggapan bahwa tidak ada masalah mengenai pengetahuan, sebab pertanyaan kritis tidak dapat diakukan secara konsisten. Bagi kalangan skeptis epistemologi, ralisme adalah suatu pengandaian pemikiran yang bersifat absolut dan setiap usaha untuk membenarkan realisme telah memberikan konsesi atau menyerah. ${ }^{20}$ Epistemologi dalam filsafat ilmu mengajukan pertanyaan-pertanyaan fundamental berikut: Bagaimana proses yang memungkinkan diperolehnya pengetahuan berupa ilmu? Bagaimana prosedurnya? Hal-hal apa yang harus diperhatikan agar kita mendapatkan pengetahuan yang valid? Apa yang disebut dengan kebenaran itu? Apa kriterianya? Cara, teknik, atau sarana apa yang membantu kita dalam pengetahuan berupa ilmu? ${ }^{21}$

Ketiga, domain aksiologis, yang mengajukan pertanyaan-pertanyaan berikut secara kritis: Untuk apa pengetahuan yang berupa ilmu tersebut digunakan? Bagaimana kaitan

${ }^{17}$ Noeng Muhadjir, Filsafat Ilmu: Telaah Sistematis, Fungsional, Komparatif, (Yogyakarta: Penerbit Rake Sarasih, 1998), h. 1.

${ }^{18}$ D.W. Hamlyn, "Epistemology, History of" dalam, The Encyclopedia of Philosophy, ed. Paul Edwards, Vol. 3 (1967), h. 8-9.

${ }^{19}$ Elliot Sober, Core Questions in Philosophy: A Text With Readings (New Jersey: Prentice Hall, 1995), h. 153.

${ }^{20}$ Kenneth T. Gallagher, Epistemologi: Filsafat Pengetahuan, disadur oleh P. Hardono Hadi dari The Philosophy of Knowlede, (Yogyakarta: Pustaka Kanisius, 1994), h. 19.

${ }^{21}$ Jujun S. Suruasumantri, Filsafat Ilmu: Sebuah Pengantar Populer,(Jakarta: Sinar Harapan, 1984), h. 33. 
antara cara penggunaan tersebut dengan kaidah moral? Bagaimana kaitan antara teknik prosedural yang merupakan operasionalisasi metode ilmiah dengan norma-norma moral/ profesional? Aksiologi dalam filsafat ilmu merupakan wacana filosofis tentang persoalan dilematis ilmu dan nilai (value) tentang apakah ilmu merupakan entitas otonom dan tertutup (science is for the sake of science olny) atau haruskah ia lebur dalam konteks (science is for the sake of buman progres). ${ }^{22}$

Filsafat Ilmu Sebagai Landasan Berpikir Analitis, Kritis dan Sintetis. Filsafat secara umum memang mencari jawaban-jawaban atas persoalan-persoalan mendalam, radikal dan terlepas dari asumsi dari doktrin atau otoritas. Akan tetapi, jawaban-jawaban yang diberikan tidak pernah dilihat sebagai sesuatu yang final dan abadi. Menurut Franz Magnis-Suseno, apa yang sering dipandang sebagai kelemahan filsafat adalah bahwa filsafat dalam abad ke-20 seperti 2500 tahun lalu menjawab persoalan-persoalan sama dengan "metodenya". Persoalan filsafat pada hakikatnya adalah isu-isu fundamental lintas historis, termasuk ilmu pengetahuan dan kemanusiaan. Namun, jawaban tak pernah berhenti pada satu titik. ${ }^{23}$

Dalam konteks kritisisme filsafat, filsafat ilmu seharusnya tidak tersekat oleh monometodologis dalam penelusuran secara filosofis (philosophical investigation), serta menurut Franz Magnis-Suseno, tidak ditarik ke dalam salah satu pengotakan sebagai "ilmu pengetahuan sekunder" atau sebagai "metascience", merupakan landasan berpikir yang kritis.

Mempelajari filsafat ilmu dihadapkan pada dua wacana; (a) aliran-aliran dominan dengan segala asumsi-asumsi dasar filosofisnya dan (b) berbagai pendekatan yang menonjol dalam pengembangn ilmu. Oleh karena itu, studi filsafat ilmu tidak hanya menjadi "historis", tapi juga "sistematis" dan "fungsional'. Dengan demikian, filsafat ilmu berakibat positif pada pelebaran wacana keilmuan dan perluasan horizon pemikiran dalam pengertian filosofis, teoretis, metodologis, hingga teknik operasional.

Filsafat ilmu menelaah secara filosofis hakikat ilmu, baik secara eksternal maupun internal. Telaahnya bersifat analitis, kritis dan sintetis. ${ }^{24}$ Telaah analitis merupakan upaya untuk mengenal ciri, sifat dan fungsi dari komponen-komponen keilmuan. Analisis ini diarahkan untuk mengenal esensi yang bersifat mendasar, yang bersifat kompromi eklektik dari berbagai elemen pemikiran yang ada. Telaah kritis merupakan proses kegiatan berpikir yang bersifat evaluatif yang menarik kesimpulan terhadap sesuatu setelah mempertimbangkan kelebihan dan kekurangan obyek telahaan tersebut. Telaah tentang hakikat ilmu, baik secara analitis maupun sintesis, harus disadari sifat berpikir kritis. Dengan pengetahuan tentang kelebihan dan kekurangan tentang ilmu, kita menempatkan ilmu pada tempatnya yang layak. Dengan demikian, telaah tersebut tidak menjadi "saintisme", atau menjadikan ilmu sebagai priferal dalam dataran pemikiran.

Berpikir secara sintetis adalah aktivitas pemikiran untuk mengkombinasikan secara kreatif dan eklektik-konstruktif komponen-komponen keilmuan yang terpisahkan untuk dikonstruksi sebagai sebuah bangunan pemikiran yang utuh, integral dengan unsur-unsur baru yang kreatif. Dalam konteks ilmu, berpikir secara analitis dan sintetis memungkinkan kita mengungkapkan hakikat sesuatu tanpa melepaskannya dari konteks secara menyeluruh. Sebagai ilustrasi, dalam proses aplikasi penelitian, misalnya, pembahasan mengenai statistika tidak terlepas dari logika induktif - diuji hipotesis - teori kebenaran korespondensi metode ilmiah. Logika induktif tak terlepas dari pengujian hipotesis. Pengujian hipotesis mendasarkan diri atas teori kebenaran korespondensi. Korespondensi sebagai teori kebenaran merupakan bagian integral dari kerja metode ilmiah secara keseluruhan.

${ }^{22}$ Tentang posisi ilmu (bebas nilai atau tidak), lihat Beerling et.al., Inleiding, h. 132-142. Tentang nilai sebagai kualitas empiris atau hanya obyek dari kepentingan, lihat Louis O. Kattsoff, Elements of Philosophy, terj. Soejono Soemargono (Yogyakarta: Tiara Wacana, 1992), h. 333-337.

${ }^{23}$ Lihat Franz Magnis-Suseno, Filsafat Sebagai Ilmu Kritis, (Yogyakarta: Pustaka Filsafat, 1992), h. 20.

${ }^{24}$ Lihat uraian tentang ini dalam Jujun S. Surasumantri, "Kata Pengantar", dalam Ilmu Pengetahuan dan Metodenya, ed. C.A. Qadir, (Jakarta: Yayasan Obor Indonesia, 1995), h. viii. 
Di samping dimensi analitis, kritis dan sintesis filsafat ilmu dengan aksentuasi pada kerangka berpikir metodologisnya (penekanan sisi epistemologis an sich), filsafat ilmu juga memiliki dimensi analitis, kritis dan sintesis ontologis, epistemologis dan aksiologis. (a) Kerangka berpikir analitis-kritis-sintetis pada tataran ontologis. Filsafat ilmu memungkinkan tidak hanya melihat secara analitis dan kritis suatu bidang ilmu obyek telaahannya, wujud hakiki darinya, serta hubungan obyek tersebut dengan proses yang mengkonstruk ilmu tersebut, tapi secara sintetis dengan sudut pandang ilmu lain secara kreatif untuk rumusan tentang ontologi keilmuan bersangkutan. Oleh karena itu, ontonomi ilmu akan disintesakan dengan pandangan ontologis bidang ilmu lain yang juga sebenarnya otonom. Secara historis, dalam perkembangan keilmuan, sosiologi, misalnya, berinteraksi dengan ilmu-ilmu kealaman (natural science) secara ontologis maupun paradigmatis. Oleh karena itu, wajar bahwa sosiologi dalam perkembangan awalnya lebih dipengaruhi oleh mainstream positivistik. Dengan kata lain, telah ada saling pandangan sintetis antara ilmu pada tataran ontologis. (b) Kerangka berpikir analitis-kritis-sintetis epistemologis. Filsafat ilmu tidak hanya secara analitis dan kritis mempersoalkan kerja metodologis ilmiah suatu bidang keilmuan, melainkan juga memungkinkan "dialog epistemologi" antar bidang keilmuan. Penerapan analisis kualitatif model statistik dalam penelitian sosial adalah satu contoh terjadinya dialog epistemologis tentang bagaimana ilmu diperoleh secara ilmiah antara wilayah naturwissenschaft dan geisteswissenchaft, atau antara ilmu-ilmu alam dan ilmu-ilmu sosial. (c) Kerangka berpikir analitis-kritis-sintetis aksiologis. Selama ini, jika kita mengetahui bahwa ilmu adalah "tidak bebas nilai" (value laden), maka kritik ilmu secara aksiologis itu sebenarnya adalah "kritik dari luar", semisal perangkat nilai kemanusiaan, religius dan sosial terhadap ilmu. Menurut penulis, secara sintetis, ilmu seharusnya juga mengembangkan "kritik dari dalam", karena ketika ilmu diciptakan pun sejak awal dilandasi oleh nilai-nilai yang dimilikinya. Dengan bentuk lain, ilmu juga mungkin melakukan kritik terhadap perangkat nilai-nilai di luarnya, seperti nilai-nilai budaya, adat, atau yang secara taken for granted diterima dengan mapan di masyarakat. Dengan demikian, ada "komunikasi aksiologis" dari dua arah.

\section{Dilema Pendidikan Tinggi Keagamaan Islam (Ptki) Di Indonesia}

Subtansi Pendidikan Tinggi: Antara Misi Intelektualitas dan Moralitas. Sebagaimana lembaga pendidikan tinggi, PTKI menempati posisi paralel dengan perguruan-perguruan tinggi lainnya bahwa landasan dan titik tolaknya adalah penyelenggara Tri Darma Perguruan Tinggi, yaitu pendidikan, pengabdian dan penelitian. Subtansi pendidikan tinggi tersebut akan menjadi dilematis jika dihubungkan realitas obyektif pendidikan tinggi di PTKI. Berbeda dengan eksistensi institut-institut lain, seperti IKIP, ISI, atau IPB, maka PTKI menghadapi sebuah dilema berupa tumpang-tindihnya misi perguruan tinggi. Meskipun tidak bersifat dikotomis dan tersekat secara ketat, dapat dilakukan pembedaan orientasi PTKI kepada dua hal. ${ }^{25}$

Pertama, orientasi yang terkait dengan eksistensi sebagai lembaga "keilmuan" atau "intelektualitas". Untuk menuju ke arah itu, PTKI dipandang untuk mengembangkan diri sebagai sebuah lembaga kajian keislaman (Islamic studies), sehingga orientasinya bersifat keilmuan murni. Penguasaan bahasa asing (Arab dan Inggris), perpustakaan yang representatif, perangkat lunak berupa formasi matakuliah dalam kurikulum yang tidak hanya preskriptif bagi khazanah intelektual keislaman klasik, tapi adatif bagi perkembangan disiplin keilmuan penduduk, adalah syarat yang harus ada (conditio sine qua non) dalam penguatan eksistensinya sebagai lembaga keilmuan. Kedua, orientasi yang terkait dengan eksistensinya sebagai lembaga "keagamaan" yang pada esensinya menegaskan "moralitas". Di sisi lain,

25Distingsi ini dikemukakan oleh M. Amin Abdullah, Studi Agama: Normativitas atan Historisitas? (Yogyakarta: Pustaka Pelajar, 1996), h. 104-105. 
dengan orientasi ini, PTKI juga perlu mengembangkan diri sebagai lembaga yang berbuat secara nyata untuk kepentingan Islam, bukan hanya sebagai lembaga atau universitas riset yang oreintasinya keilmuan secara murni, melainkan berbuat untuk kemajuan Islam.

Pada dataran pemikiran, sebenarnya tidak ada dikotomi antara "keilmuan" dan "keagamaan", atau antara "intelektualitas" dan "moralitas". Namun, pada dataran praktis, yang pertama mengasumsikan perlunya pendekatan kritis, analitis, empiris dan historis, sehingga harus bersentuhan dengan wilayah yang "ditabukan" di kalangan ortodoks muslim, semisal pendekatan filosofis, antropologis dan sebagainya, sedangkan yang kedua lebih menuntut civitas akademik untuk idealisasi pengembangan jati diri keislaman. Dengan meminjam istilah "actor" dan "spectator", maka orientasi keilmuan ketika berhadapan dengan wacana keilmuan berlaku sebagai "spectator" dan orientasi keagamaan akan meleburkan diri ke dalam "actor". Sebagai contoh, dalam hal penelitian, misalnya, PTKI perlu secara akademis meneliti fenomena kekerasan berbasis justifikasi dari ayat-ayat al-Qur'an yang berkembang di kalangan Islam radikal di Indonesia selama ini. Namun, riset saja tidaklah cukup untuk pengembangan jati diri lembaga. PTKI juga perlu mengembangkan penafsiranpenafsir secara inklusif dan moderat terhadap ayat-ayat al-Qur'an sebagai suatu "keberpihakan positif" terhadap persoalan itu.

Posisi dilematis tersebut lebih tampak ketika pendekatan ilmiah Barat ingin diterapkan dalam kajian-kajian keislaman. Salah satu keberatan teologi dalam konteks itu antara lain diungkapkan oleh Perre L. Van den Breghe, "Setidaknya, ada banyak orang yang mengakui bahwa kemurnian ilmu mungkin sebenarnya dicemari oleh virus ideologi, tapi mereka juga percaya bahwa infeksi itu bisa dihindari dan bahwa ilmu bisa bebas-nilai “. ${ }^{26}$ Di satu sisi, memang ada kemungkinan bahwa ilmu bisa dimasuki oleh kepentingan ideologi, seperti tampak dari banyak kritik, seperti kritik M. Dawam Rahardjo, terhadap perkembangan ilmu sosial di Barat yang diwarnai dan ditunggangi oleh kepentingan kolonialisme. Itu artinya, kita memang menginginkan bahwa ilmu adalah bebas nilai. Akan tetapi, di sisi lain, bebas nilai itu juga problematis, karena setidaknya ilmu harus diabdikan untuk kepentingan kemanusiaan, sebagaimana halnya juga bahwa pengembangan ilmu di PTKI juga harus bermanfaat bagi Islam sendiri.

Beberapa kritik yang ditujukan kepada PTKI antara lain adalah ditemukannya indikator paradoks. Johan H. Meuleman ${ }^{27}$ mengatakan bahwa IAIN (baca: PTKI) sedang berada di "persimpangan jalan". Posisi tersebut, menurutnya dan menurut sebagian pengamat lain, disebabkan oleh karena PTKI laksana "motor assemblingan" yang bahanbahannya berasal dari banyak tempat yang terkadang tidak sinkron. ${ }^{28}$

Jika dipetakan secara kasar, ada dua tradisi keilmuan yang saling tarik menarik. Pertama, tradisi keilmuan normatif religius yang berkembang semula di Hijaz dan Mesir. Agaknya, tradisi keilmuan Islam model ini tampaknya menjadi anutan mainstream kajian hampir semua PTKI di seluruh Indonesia. Kedua, tradisi keilmuan Barat yang berkembang di universitas-universitas Barat yang menyelenggarakan program studi Islamic studies, semisal McGill Universitas Canada, University of Lieden dan University of California Los Angles (UCLA).

Posisi dilematis dan ketegangan yang ada tersebut akan menimbulkan proses dialektika internal dan keadaan saling kontrol, seperti dialektika antara "otonomi ilmu" dan "ikatan nilai/ value". Akan tetapi, dalam konteks di atas, tarikan "keagamaan" terhadap "keilmuan" menimbulkan apa yang disebut sebagai islamisasi sains. Sebaliknya, tarikan "keilmuan"

${ }^{26}$ Dikutip dari Editorial "A Problem of Methodology in Islamic Studies, al-Jami'ab: Journal of Islamic Studies, No. 61 (1998), h. iii.

${ }^{27}$ Johan H. Meuleman, "IAIN di Persimpangan Jalan", dalam PERTA: Jurnal Pendidikan Tinggi Islam, Vol. 8, No. 1. (1990), h. 21-22.

${ }^{28}$ Lihat Donald Malcolm Reid, "Al-Azhar", dalam The Oxford Encyclopedia of the Modern Islamic World Vol. I, ed. John L. Esposito (Oxford: Oxford University Press, 1955), h. 168. 
terhadap "keagamaan" akan mengakibatkan apa yang disebut "sekularisasi", atau rasionalisasi doktrin agama. Jadi, ketegangan itu sendiri memunculkan dinamika akibat adalah tantangan dan peluang.

Dua Kemiskinan: Problematika Eksistensial Keilmuan. (a) Kemiskinan Filsafat. Meminjam dalam pembedaan filosofis, ada interrelasi antara esensi dan eksistensi. Eksistensi sendiri tergantung pada esensi. Dalam filsafat eksistensialisme, esensi harus diisi dengan eksistensi. Dalam filsafat Rene Descartes, "Cogito Ergo Sum" (I am thinking, therefore I exist), eksistensi manusia tergantung pada aktivitas berpikir. Filsafat adalah salah satu bentuk berpikir, namun "radikal" (menukik ke akar persoalan), universal dan mendalam. Dengan meminjam cara berpikir seperti itu, saya melihat bahwa salah satu problematika eksistensial keilmuan masyarakat akademis PTKI adalah kemiskinan filsafat, meminjam istilah Karl Marx "the poverty of philosophy". Yang dimaksud dengan "kemiskinan filsafat" adalah bahwa porsi keilmuan PTKI belum memberikan bekal yang memadai bagi mahasiswa untuk berpikir reflektis, filosofis, kritis, analitis, bahkan sintesis. Porsi ini adalah porsi berpikir yang menjadi inti eksistensi manusia, seperti tampak dari filsafatnya itu. Misi keilmuan menjadi pengisi secara esensial terhadap eksistensi PTKI yang sudah terbangun. Dengan esensi keilmuan itu, PTKI bisa mengembangkan dirinya. Itu artinya, jika esensi keilmuan ini hilang, maka hilang juga esensinya sebagai perguruan tinggi. Dalam konteks itu, PTKI harus mandiri dalam berpikir, tidak hanya bertaklid kepada khazanah lama melulu, tapi juga mengembangkan keilmuan melalui riset-riset. Begitu juga, kemandirian itu bermakna bahwa tidak boleh ada intervensi dari luar, seperti kepentingan politik, dari perorangan atau kelompok.

Perguruan tinggi didesain oleh kurikulum yang akan mementukan arah pembelajaran. Matakuliah filsafat yang umumnya dipelajari di semua fakultas adalah filsafat umum, sedangkan filsafat ilmu hanya dipelajari di Jurusan Agama dan Filsafat di Fakultas Ushuluddin dan Humaniora di stara satu (S1) dan di pascasarjana (S2 dan S3), padahal filsafat ilmu memuat paradigma filosofis, seperti aliran rasionalisme, empirisisme dan pragmatisme yang kemudian mendasari pendekatan-pendekatan dalam mata kuliah metodologi penelitian. Mahasiswa-mahasiswa pascarjana pun yang sebelumnya belum mempelajari filsafat ilmu ketika studi di S1 agak dikejutkan dengan bahasan-bahasan dalam mata kuliah filsafat di S2. Seharusnya, filsafat ilmu memang sudah dipelajari di jenjang S1. Di konsentrasi pendidikan Islam, filsafat yang diajarkan adalah filsafat pendidikan Islam. Mata kuliah ini tidak memadai jika hanya mata kuliah ini saja yang dipelajari satu-satunya.

Secara umum, selama ini pembelajaran filsafat pada dasarnya dapat dibedakan dengan dua pendekatan, yaitu (1) pendekatan historis dengan perkembangan pemikiran filsafat yang umumnya bertumpu pada ketokohan, seperti filsafat Plato dan Aristoteles, filsafat Ibn Sînâ dan Ibn Rusyd; (2) pendekatan tematis yang menelaah tema-tema tertentu filsafat secara mendalam dan komprehensif, seperti filsafat etika menurut Aristoteles dan filsafat kebahagiaan menurut al-Fârâbî.

Filsafat umum yang dipelajari di PTKI belum mampu mengantarkan mahasiswa ke horizon pemikiran yang bersifat metodologis, filosofis, analitis, kritis dan sintetis, karena baik dilihat historis maupun tematik belum memadai untuk membekali mahasiswa memahami persoalan-persoalan penting, apalagi filsafat ini hanya diidentikkan dengan filsafat alam (Yunani).

Jika dirunut kebelakang tentang faktor-faktor penyebab terjadinya "kemiskinan filsafat" (the poverty of philosophy), pengkondisian ke arah itu, menurut saya, lebih disebabkan faktor internal. Pertama, di kalangan akademisi Islam pendidikan umum sebenarnya masih ditemukan indikasi tentang "resistensi" terhadap pemikiran rasional, bahkan resistensi terhadap pemikiran modern, sehingga filsafat ilmu sebagai cabang filsafat kurang ditempatkan pada posisinya yang layak dalam orientasi akademis. PTKI di satu sisi kemasukan paham Islam Salafí yang menanggap bahwa filsafat, bahkan ilmu Kalâm (teologi 
Islam), diharamkan, karena dianggap tidak ada preseden dari Nabi Muhammad yang menganjurkan mempelajari ilmu ini. Di sisi lain, beberapa komentar negatif dari luar PTKI juga ikut mewarnai dan mempengaruhi gairah keilmuan di PTKI. Tulisan-tulisan Hartono Ahmad Jaiz, misalnya, yang menyebut ada pemurtadan di PTKI dan pemikiran liberal juga diamini oleh tidak hanya orang-orang di luar PTKI, tapi juga oleh orang-orang dalam PTKI sendiri. Pemurtadan itu disebut sebagai akibat pemikiran liberal yang, antara lain, disebabkan oleh diajarkannya filsafat di PTKI.

Kedua, etos keilmuan di perguruan tinggi Islam melemah, karena kesalahan interpretasi terhadap doktrin-dokrin tertentu agama, terutama doktrin sufistik semisal asketisme (zuhud), tawakkal dan sabar. Dengan ungkapan lain, "kemiskinan filsafat" (the poverty of philosophy) mungkin disebabkan oleh "filsafat tentang kemiskinan" (the philosophy of poverty), dengan pengertian bahwa melemahnya etos keilmuan dijustifikasi, melalui pemahaman dan interpretasi yang keliru, oleh doktrin-doktrin keagamaan.

(b) Kemiskinan Metodologi: Krisis Epistemologi. Menurut Hasan Hanafî, ${ }^{29}$ tokoh hermeneutika pembebasan al-Qur'an kontemporer dan penulis Muqaddimah fì Tlm al-Istigrâb (Pengantar Oksidentalisme), pendidkan Islam dalam bidang pemikiran (filsafat Islam, teologi dan sufisme) Islam seringkali terkesan hanya merupakan "transfer teks ke realitas" dan kurang menyentuh bahasan metodologi tentang bagaimana rekonstruksi pemikiran tokoh terdahulu dalam memajukan masyarakat, sehingga kehilangan relevansinya dengan isu-isu kekinian.

Penyelenggaraan pendidikan tinggi secara umum dan di IAIN secara khusus, masih menganut pola kebijakan "bagaimana memberikan pendidikan kepada mahasiswa seperangkat mata kuliah yang seluas-luasnya dari aspek kuantitas materi", bukan "bagaimana memberikan bekal pengetahuan tentang materi kuliah (setelah proses perampingan) secara mendalam dari aspek metodologi". Sebagai konsekuensi logisnya, "krisis epistemologi" merupakan realitas umum yang diderita oleh dunia perguruan tinggi. Indikasinya antara lain adalah kurangnya kepekaan terhadap masalah penelitian dan "kepekaan terotiris", ${ }^{0}$ meminjam istilah dalam penelitan model grounded research.

Masalah ini hanya merupakan awal persoalan yang akan berbuntut lebih serius, yaitu kaitannya dengan krisis epistemologi di dunia pendidikan Islam dan benturannya dengan modernisme dan modernisasi. Kegagalan modernisme dan modernisasi Barat dengan segala remifikasinya di kalangan kaum muslimin sering dikaitkan orang dengan kekeliruan epistemologi ilmu pengetahuan dan teknologi yang berkembang pasca-Aufklarung dan Revolusi Industri di Eropa. Berbeda dengan epistemologi ilmu pada abad pertengahan yang bersifat "teosentris", epistemologi ilmu modern dan kontemporer lebih bersifat "antroposentris". 31

Di kalangan Barat, paradigma epistemologi "antroposentris" hampir sepenuhnya menggeser paradigma "teosentris". Sebaliknya, di kalangan pemikir Islam terjadi "tariktambang" yang sangat instens di kalangan masing-masing pendukung paradigma. Pemikir modernis seperti Muhammad 'Abduh dan Sayyid Amir Ali, misalnya, mengembangkan paradigma ilmu yang kurang lebih "antroposentris". Sebaliknya, pemikir neo-tradisional,

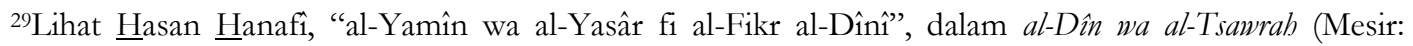
Maktabat Madbûlî, t.th), Juz vii.

${ }^{30}$ Kepekaan terhadap masalah adalah kemampuan manusia untuk melihat keadaan secara baru pada waktu di permasalahkan. Menurut J. Bronowski, kepekaan masalah adalah keinsyafan akan kedwiartian gejala yang merangsang khayalan untuk menemukan hal-hal yang baru. Lihat C.A Van Peursen, De Opbhuw van de Wetenschap, diterjemahkan oleh J. Drost dengan judul Susunan Ilmu Pengetahuan (Jakarta: Gramedia, 1985), h. 108. Tentang "kepekaan teoretis", lihat Anselm Strauss dan Juliet Corbin, Basic and Techniques, disadur oleh M. Djuanidi Ghony (Surabaya: Bina Ilmu, 1997), h. 39-45.

${ }^{31}$ Lihat Azyumardi Azra, Pendidikan Islam: Tradisi dan Modernisasi Menuju Millenium Baru (Jakarta: Logos, 1999), h. 40. 
seperti seyyed Hossen Nasr, setelah mengkritik keras epistemologi Barat, lantaran menganjurkan paradigma epistemologi yang bersifat "teosentris". Tarik-tambang dalam perbenturan pemikiran epistemologi tersebut semakin marak dengan ide "islamisasi ilmu pengetahuan", proyek pemikir semisal Ismail R. al-Faruqi dan S. M. Naquib al-Attas.

Dalam konteks Indonesia, modernisasi sistem dan lembaga pendidikan Islam yang berlangsung sejak awal abad ke-20 nyaris tak melihat wacana epistemologi. Modernisasi dan modernisme cenderung diadopsi di implementasikan begitu saja, sehingga berlangsung secara ad hoc (sementara) dan parisal. Alih-alih membuka wacana epistemologi untuk penentuan identitas keilmuan Islam, dasar-dasar epistemologi Barat yang telah berakar maupun belum dipahami dengan baik oleh kalangan akademis PTKI.

Penelitian-penelitian yang dilaksanakan sering hanya diarahkan untuk pemecahan masalah yang sifat sesaat atau lebih bersifat "konsumtif". Idealnya adalah harus ada pergeseran dari pola "pragmatisme" penelitian ke "idealisme" penelitian, yaitu pengembangan teori atau ilmu dalam sebuah kerangka yang lebih universal, dengan perkembangan teori ilmiah yang tidak pernah berakhir. Ini disebabkan karena bobot akademik suatu ilmu terletak pada proses pengembangan metodologi yang semakin canggih, buka pada hasil akhir temuannya. Oleh Kerlinger dikatakan, ${ }^{32}$

The basic ail of science is not the betterment of mankind, but the theory. A theory is not the betterment of mankind, but the theory. A theory is a set of interrelated construct (concept), definitions, and proposition that present a systematic view of phenomena by specfying relation among variables, with the purpose of explaining and predicing the phenomena.

Jika yang diinginkan dari masyarakt akademik PTKI, agaknya terlalu dan semakin jauh kesenjangan antara yang ril (is) dan yang seharusnya (ought).

Antara Ilmu Murni (Pure Science) dan Ilmu Terapan (Applied Science). Yang dimaksud dengan ilmu-ilmu murni adalah kelompok ilmu-ilmu seperti fisika, kimia, matematika dan biologi, sedangkan yang dimaksud dengan ilmu-ilmu terapan adalah kelompok ilmu-ilmu seperti teknik, kedokteran dan pertanian. Jika dalam wilayah ilmu-ilmu alam terdapat kelompok ilmu-ilmu alam terapan (applied natural sciences), dalam bidang ilmu-ilmu sosial dan kemanusiaan dan kelompok ilmu-ilmu sosial terapan (applied social sciences). ${ }^{33}$

Dalam konteks pendidikan tinggi di PTKI, baik pure science maupun applied science, terutama yang berkaitan dengan pengembangan studi-studi Islam, tampaknya masih "tercecer". Mata kuliah Ilmu Alamiah Dasar (IAD) yang lebih merupakan kombinasi kajian fisika sering diajarkan oleh dosen yang bukan latar belakang keilmuannnya. Sebaliknya, dalam bidang terapan, kajian-kajian Islam sebagai fenomena budaya, historis, sosiologi dan antropologis masih berjalan tak seimbang dengan kajian-kajian Islam doktrinal (seperti fiqh, tafsir dan sufisme). Problemnya adalah kurangnya penguasaannya terhadap disiplin ilmu tersebut dan minimnya landasan filosofis yang mendasari sebuah kerja penelitian tentang pendekatan model apa (positivistis, fenomologi, atau hermeneutis) yang harus diterapkan. Analisis yang dilakukan oleh Azyumardi Azra ${ }^{34}$ tentang kecenderungan kajian Islam pada disertasi-disertasi di UIN Syarif Hidayatullah sejak tahun 1982 hingga tahun 1996 dengan sangat jelas menunjukkan supremasi kajian ilmu-ilmu agama dan "kegagalan" kajian sosiologis dan antropologis.

32Sebagaimana dikutip Mastuhu, Memberdayakan Sistem Pendidikan Islam (Jakarta: Logos, 1999), h. 149.

33"Ilmu murni adalah ilmu yang bergantung pada deduksi dari kebenaran yang dibuktikan dari diri sendiri (self-evident), seperti matematika, logika, atau ilmu yang mengkaji tanpa aplikasi praktik, sedangkan ilmu terapan adalah ilmu yang melakukan pengkajian untuk diaplikasi dengan praktik". J. B. Sykes (ed), The Concise Dictionary (Oxford: The Clarendom Press, 1976), h. 1014.

${ }^{34}$ Lihat Azyumardi Azra, Pendidikan, h. 182 dan h. 196. 
Moralitas Kampus Dalam Sorotan: Keterpisahan Etika Religius dari Etika Rasional-Filosofis. Dilema-dilema intelektualitas yang dihadapi oleh IAIN ternyata bersentuhan secara paralel dalam suatu interrealisisi dan interdepensi dengan dilema "moralita", sebuah lingkaran setan dan siklus problema yang terputu. George F. Hourani mengklasifikasikan etika kepada dua macam, yaitu theistic subjecctvism atau ethical voluntarism dan rationalistic subjectivism. ${ }^{35}$ Apa yang berkembang dan diyakini umumnya di kalangan akademis Islam sekalipun adalah kecenderungan kepada ethical voluntarism, yaitu etika yang didasarkan atas teks-teks suci keagamaan. Kuatnya pemikiran sufisme di PTKI memungkinkan hanya bagi etika model itu. Etika seharusnya juga di bangun di atas kesadaran kemanusiaan secara filosofis dan rasional. Dengan itu, akan mungkin terjadi dialog kemanusiaan. Dengan kata lain, etika religius di IAIN telah mengalami keterpisahannya dengan etika rasional-filosofis, sehingga "filsafat moral/ etika" seharusnya dijadikan komponen integral kurikulum PTKI. Etika mistisnya alGhazali yang telah lama mengkristal dalam struktur akademis Islam, misalnya, yang didasarkan atas pendekatan hipotesis (bipothetical approach) diandaikan memberikan ruang bagi etika rasionalnya Immanuel Kant yang didasarkan atas pendekatan analitias (analitical approach). Agaknya, filsafat etika lah yang mampu menjembatani keterpisahan dua wilayah etika dalam kultur akademik PTKI.

\section{Proyeksi Pengembangan Ptki Masa Depan: Perspektif Filsafat Ilmu}

Jurgen Habermas dalam sebuah kumpulan kuliah yang pernah disampaikannya, The Philosophycal Discourse of Modernity (Wacana Filsalat Tentang Modernitas), menjelaskan bahwa Immanuel Kant mengkontraskan dua macam konsep filsafat. Pertama, konsep filsafat yang mendunia (worldly concept of philosophy), yaitu apa yang diarahkan kepada kepentingankepentingan manusia. Kedua, konsep filsafat secara akademis (academic concept of philosophy). ${ }^{36}$

Filsafat ilmu yang ingin dikembangkan diorientasikan pada dua tataran tersebut, tak hanya merupakan pemikiran refleksi kritis dan abstrak, tapi menyentuh tataran realitas pendidikan.

Skema Umum Dasar Pengembangan. Secara umum, pendidikan mempunyai unsur triadik, yaitu (1) sistem pendidikan, (2) subyek pendidikan dan (3) dunia kehidupan. Penerapan filsafat ilmu, terutama epistemologi, adalah dalam penyusunan sistem pendidikan. Determinan-determinan kehidupan yang diterapkan adalah: (1) tata dan tendensi kehidupan dalam masyarakat, semisal dasar dan tujuan kehidupan, serta nilai, (2) struktur-struktur bidang kehidupan, semisal sosial budaya, politik dan ideologi dan (3) pandangan terhadap manusia. Determinan-determinan tersebut oleh epistemologi diajukan ke dalam dunia pendidikan. Sistem pendidikan berusaha menetapkan unsur-unsur pendidikan, (3) bentukbentuk pendidikan, (4) pengolalaan. ${ }^{37}$ Penerapan filsafat ilmu dalam pendidikan akan mempertanyakan bagaimana upaya-upaya pendidikan dipandang sebagai hal yang sah secara ilmiah. Sebagai konsekuensinya, langkah-langkah teknis, operasional, atau kebijakan apa yang timbul sebagai akibat dari penerimaan itu. Proyeksi pengembangan IAIN dalam perspektif filsafat ilmu di sini diorientasikan kepada upaya-upaya pendidikan sebagai bagian dari sistem pendidikan tersebut.

Integrasi Filsafat Ilmu dan Ilmu-Ilmu Keislaman: Restrukturisasi Kurikulum. Sebagai pusat keilmuan dan penelitian Islam, idealnya adalah bahwa program-program studi di PTKI berkaitan dengan disiplin-disiplin keagamaan selain menekankan bidang-bidang Islamic studies, juga memberikan kesempatan bagi penguasaan disipilin-disiplin keilmuan umum

${ }^{35}$ Lihat M. Amin Abdullah, Studi, h. 63.

${ }^{36}$ Lihat Jurgen Habernas, The Philosophy Discourse of Modernity: Twelve Lectures, trans. Frederick G. Lawrence (Massachusetts: The MIT Press, 1996), h. 52.

${ }^{37}$ Antun Suhono, "Pendidikan dan Epistemologi", dalam Epistemologi Kebudayaan dan Pendidikan, ed. AMW. Pranakarta dan Anton Bakker (Yogyakarta: Kelompok Studi Filsafat Yogyakarta, 1979), h. 144-151. 
secara metodologi. Hal ini meniscayakan adanya upaya restruksisasi kurikulum dan tinjaun terhadap matakuliah-matakuliah umum, yang mempunyai relevansi dengan Islamic studies. Perlu adanya penciptaan sistem dan mekanisme sendiri yang memungkinkan alokasi bagi pemberian mata kuliah umum. Selama ini ada kecenderungan terjadinya tumpang-tindih mata kuliah umum dalam berbagai strata pendidikan.

Sebagai lembaga pendidikan tinggi dengan visi keilmuan dan keagamaan yang melekat padanya, maka upaya restrukturisasi kurikulum tetap mendasarkan diri atas "konvergensi antara kesadaran rasionalitas dan kesadaran spiritualitas". Atas dasar ini, upaya integrasi filsafat ilmu dengan ilmu-ilmu keislaman diproyeksikan ke arah berikut. Pertama, usaha restrukturisasi ekstensif (perluasan). Hal ini didasarkan atas kondisi dilematis yang dihadapi, yaitu kemiskinan filsafat dan kritis epistemologi. Filsafat ilmu harus dimasukkan ke dalam kurikulum PTKI program sarjana (S1) sebagai matakuliah yang dipelajari oleh semua fakultas. Sebagai aplikasinya dalam kajian-kajian keislaman, maka idealnya harus ada kajian tersendiri tentang filsafat ilmu-ilmu sosial dan kajian keislaman yang membahas asumsi dasar dan pendekatan (semisal fenomenanologi sosial-antropologis, positivisme sosiologis) dalam kajian keislaman. Matakuliah ini terfokus pada bahasan tentang landasan filosofis pendekatan, yang berbeda dengan matakuliah Metodologi Studi Islam (MSI) yang terarah pada teknik operasional. Tampaknya, matakuliah ini harus diintegrasikan sebagai komponen umum. Kedua, usulan pendalaman (meski tidak diintegrasikan ke dalam kurikulum), yaitu dalam bentuk: (a) kursus literatur filsafat yang memberikan pengetahuan kepada mahasiswa tentang pemetaan literatur-literatur filsafat secara luas (bahasa Indonesia, Inggris, Arab, Perancis dan Jerman) yang dilaksanakan awal kegiatan kuliah dan kegiatan ini tidak dimasukkan ke dalam kurikulum, tapi kegiatannya secara struktural merupakan kegiatan formal universitas; (b) di dunia Islam, hingga kini sedang berkembang wacana epistemologi di kalangan pemikir Islam kontemporer, semisal Mohammad Arkoun dengan dekonstruksinya ala Derrida, Fazlur Rahman mengembangkan hermeneutika kontemporer al-Qur'an dan Muhammad 'Abid al-Jâbirî cendurung juga melahirkan epistemologi yang juga khas, sehingga pergulatan wacana yang hiruk-pikuk di dunia Islam tersebut mengandaikan adanya apresiasi akademis yang memadai untuk dikaji secara tersendiri.

Usulan-usulan tersebut sebenarnya tidak berlebihan. Tradisi intelektualitas Iran dengan mullah-mullabnya yang bergulat dengan pemikiran filsafat Barat dan Islam, justru lahir dari idealisme seperti itu bahwa filsafat harus "ditradisikan". Seyyed Hossein Nasr, dalam eseinya "The Teaching of Philosophy", dalam Philosophy, Literature, and Fine Arts, menyarankan sebagai berikut, ${ }^{38}$

"Program pendidikan bagi pengajaran filsafat Islam harus dimulai pada tingkat sekolah menengah dan bahkan pada tingkat sekolah dasar dan bukan semata terbatas pada universitas. Sejak dari kelas yang awal sekali acuan buku-buku teks untuk murid-murid muslim seharusnya diutamakan pada tokoh-tokoh muslim..."

Idealisme yang dikemukakan oleh Nasr tersebut membuat kita sulit untuk menurunkannya ke dataran realitas, karena problematisnya persoalan-persoalan filsafat. Akan tetapi, pengajaran filsafat harus mampu menembus batas-batas formal dan kaku suatu metode pengajaran. Oleh Gerald Runkle, dalam Theory and Practice: An Introduction to Philosophy, diarahkan begini, ${ }^{39}$

"The are many ways by which a student can be intorduced to philosophy. One way would be a course in one of its traditional fields - logic of ethics. Another would be a course in its history - Thales to Sartre. Still another would be a course dealing

${ }^{38}$ Dikutip dari Ali Ashraf, Horison Baru Pendidikan Islam, terj: Sori Siregar (Jakarta: Pustaka Firdaus, 1996), h. 66.

${ }^{39}$ Dikutip dari The Liang Gie, Philosophy, h. 176. 
with all of its main branches where in the student in confronted with conflicting answers to basic philosophical problem."

"Its is this third approach that is favored by teachers who what their students to become familiar with the whole terrain of philosophy, to know something about all the continents that comprise it."

Dari kutipan ini, ada tiga cara atau pendekatan dalam mengkaji filsafat. Pertama, pendekatan tematik, yaitu mengkaji tema-tema filsafat. Dalam hal ini, Nasr menyarankan perlunya mempelajari isu-isu "tradisional" yang umum dan standar untuk dipelajari dalam filsafat, seperti logika yang mendasari pertimbangan etika (biasanya disebut sebagai etika rasionalis). Kedua, pendekatan historis, yaitu mengkaji tokoh-tokoh filsafat dengan pemikirannya dari periode ke periode, dari awal hingga perkembangan terakhir. Dalam hal ini, Nasr menyarakan agar filsafat dipelajari dari perkembangan awalnya dari filsafat Yunani kuno, seperti filsafat Thales, Aristoteles dan Plato, hingga filsafat Barat modern, seperti filsafat Sartre (aliran eksistensialisme). Tentu saja, Nasr tidak mengecualikan perkembangan filsafat Islam untuk dipelajari. Ketiga, pendekatan yang bisa kita sebut sebagai pendekatan konstekstual, yaitu mengkaji isu-isu modern yang kemudian dijawab dengan bahan-bahan filsafat, seperti modernisme, neo-modernisme, pasa/ post-modernisme yang membawa isuisu filsafat di dalamnya. Cara terakhir ini dimaksudkan untuk "membumikan" filsafat, agar filsafat tidak terkesan hanya sebagai olah rasio, yang tidak merespon realitas kekinian.

Kajian Keislaman Dalam Paradigma Filsafat Ilmu. Sebelum mengelaborasi bagaimana kajian-kajian keislaman harus digerakkan dalam kerangka filsafat ilmu, pemetaan kasar tentang wilayah kajian keislaman adalah penting. Dalam bukunya, Islam and Modernity: Transformation of an Intellectual Tradition, Fazlur Rahman membuat distingsi Islam kepada dua wilayah, yaitu "Islam normatif" (normative Islam) dan "Islam historis" (bistorical Islam). ${ }^{40}$ Islam model pertama adalah Islam yang masih mengkristal dalam doktrin-doktrin normatif teksteks al-Qur'an dan Hadits, yang sebenarnya tidak ada sekat yang ketat dengan Islam model kedua, yaitu Islam yang bersentuhan ide, gagasan dan interpretasi (Islam budaya), atau yang telah mewujud dalam interaksi sosial (Islam sosial). Dengan distingsi tersebut, Rahman ingin mempertahankan normativitas Islam, sambil mengkritisi potret perkembangan historisnya. Dengan demikian, konstruksi dan formulasi ilmu-ilmu keislaman, seperti teologi Islam, fiqh atau filsafat Islam sebenarnya adalah produk pemikiran manusia. Pada konteks tertentu, mereka sekaligus merupakan "prisoner of their principles", karena konteks ruang dan waktu yang membatasinya. Lantas, mengapa hanya sedikit kemajuan dan perkembangan dalam diskursus ilmu-ilmu keislaman sejak abad pertengahan hingga dewasa ini, padahal perubahan secara konstan terjadi dalam tataran konsep, metodologi, kerangka, pendekatan, diskursus dan teori, atau semua aspek pengetahuan manusia? Fazlur Rahman mengevaluasi kritis keadaan ilmu-ilmu keislaman, ${ }^{41}$

"With the habit of writing commentaries for their own sake and the steady dwindling of original thoughts the Muslim world witnessed the rise of a type of scholar who was truly encyclopaedic in the scope of learning, but hadits little new to say anything. The category of Scholar-cumcomemntator must be distingiushed on the one hand from a very different type a comprehenzive thinker like Aristotle or even lesser figure like Ibn Sina, who welded a variety of fields of inqury into unified system and coherent world view, and on the other hand from the modern type of specialist whose knowledge has extremely narrow confiness."

${ }^{40}$ Fazlur Rahman, Islam and Modernity: Transformation of an Intellectual Tradition (Chicago dan London: The University of Chicago Press, 1982), h. 78.

${ }^{41}$ Dikutip dari M. Amin Abdullah, "A Preliminary Remark on the Philosophy of Islamic Religious Science", dalam al-Jami'ab: Journal of Islamic Studies, No. 61 (1998), h. 4. 
Dari kutipan di atas, menurut Fazlur Rahman, ada beberapa tipe pemikir dan kaitannya dengan pengembangan kajian keislaman yang ideal. Pertama, ulama yang ensiklopedik yang menguasa banyak ilmu, seperti yang disinggungnya di sini, tampak pada para penafsir (mufassir) al-Qur'an. Seorang penafsir memang dituntut untuk menguasai banyak ilmu, seperti ilmu kebahasaan (nabnwu, sharf, balâghah, ilmu tawhîid, ushûl al-fiqh dan ilmu-ilmu lain yang terkait dengan kandungan ayat yang sedang ditafsirkan). Bahkan, seorang penafsir tafsir saintifik (al-tafsir al-ilmî) dituntut oleh menguasai ilmu-ilmu bantu tafsir dan ilmu pengetahuan (sains), sehingga penafsir tersebut sekaligus juga merupakan ilmuwan. Perkembangan seperti lebih marak pada tafsir dibandingkan hadîts. Kedua, pemikir komprehensif, seperti Aristoteles dari Yunani atau setidaknya Ibn Sînâ dari Islam, yang mampu memahami berbagai macam ilmu disertai dengan pemahaman tentang pandangandunia (worl-view) yang mendasarinya. Yang dimaksud dengan pandangan-dunia adalah pandangan yang komprehensif dan mendalam tentang sesuatu, yang terkait dengan asumsi dasar, pandangan pokoknya dan metodologinya. Dua figur yang disebut oleh Fazlur Rahman di sini adalah dua orang filosof, karena dengan filsafatlah bisa dipahami segala hal yang mendasari ilmu. Berbeda dengan pemahaman filosof, pemahaman muafssir-saintis (ilmuwan) tentang ilmu-ilmu tidak secara integratif. Persamaaan antara kedua "ilmuwan" ini (filosof dan mufassir-saintis) adalah bahwa keduanya ilmuwan generalis. Ketiga, pemikir spesialis yang hanya memahami satu bidang ilmu tertentu dengan pemahaman yang sempit, seperti para fuqahâ yang hanya mengetahui fiqh atau teolog yang hanya memahami teologi saja.

Dalam konteks distingsi Islam normatif dan Islam historis, maka integrasi ilmu dari perspektif filsafat meniscayakan agar Islam dikaji secara komprehensif dan integratif, tidak parsial, dengan memahami dasar-dasarnya, sumber-sumbernya, metode-metodenya, dimensi normatif-historis, sehingga keseluruhan Islam sebagai sebuah pandangan-dunia bisa dipahami dengan baik.

Pemahaman tentang Islam secara komprehensif juga mengharuskan keterbukaan terhadap kritik. Evaluasi kritis Rahman terhadap ilmu-ilmu keislaman dapat diartikulasikan dalam bahasa filsafat ilmu kontemporer, sebagaimana dalam tulisan-tulisan Karl R. Popper, Thomas S. Khun dan Imre Lakatos. Dengan paradigma filsafat ilmu kita mungkin mempertanyakan: "Mengapa dalam ilmu-ilmu keislaman kita menentukan begitu banyak "context of justification" di bandingkan dengan "context of discovery". Dalam istilah kritis Thomas S. Khun, "Mengapa wacana ilmu keislaman lebih banyak berkutat dalam wilayah "normal science" dibandingkan "revolutionary science"?, atau dalam istilah Imre Lakatos, diskusi keislaman lebih berkisar pada bidang "Hard core" dibandingkan "protective belt"?

Karena anomali-anomal dalam wacana keilmuan Islam tersebut, Mohammad Arkoun tergugah untuk melakukan reevaluasi dalam kerangka epistemologi, yang diistilahkan dengan "al-naqd al-ibistimi" (kritik epistemologi) atau critical reappraisal of the epistemic framework of the Islamic cognitive. ${ }^{42}$

Kita akan mengemukakan pemikiran tiga tokoh filsafat ilmu abad ke-20 tersebut secara sekilah. Karl R. Poper memperkenalkan "epistemologi pemecahan masalah". Kemajuan ilmu, menurutnya, adalah melalui proses eliminasi kesalahan (eror elimination). Suatu teori ilmiah, menurutnya, harus dapat difalsifikasi atau dibuktikan salah. Thomas S. Khun menyatakan bahwa peralihan dari suatu teori ke teori lain bukan karena argumen dan penalaran logis, tapi karena adanya pergeseran paradigma (shifting paradigm). Pergeseran itulah yang disebutkannya sebagai "revolusi ilmiah".

Berbeda dengan Popper dan lebih sehaluan dengan Thomas S. Khun, Imre Lakatos, menyangkal kemungkinan experimentrum crucis (bahwa falsifikasi dapat menghancurkan suatu

${ }^{42}$ Abdullah, “A Preliminary Remark...", h. 4. 
teori). Menurutnya, yang terjadi dalam pembaruan suatu ilmu sebenarnya merupakan peralihan dari teori ke teori. Dengan ungkapan lain, yang berlangsung adalah "program penelitian", yang terdiri dari tiga elemen: (1) hard core (heuristik negatif) asumsi dasar, (2) heuristik positif dan (3) serangkaian teori. ${ }^{43}$

Barangkali, adalah tidak relevan untuk menerapkan secara spesifik pandangan atau asumsi-asumsi dasar filsafat ilmu baru dan perdebatan mereka tersebut dalam kerangka kajian keislaman secara langsung. Namun, benang merah yang menghubungkan perbedaan tersebut adalah bahwa perlunya mengkaji ulang, revaluasi, mengkritisi, mempertanyakan ulang, atau hingga batas-batas tertentu "mentafalsifikasi" dalam istilah Khun, ilmu-ilmu keislaman. Hal ini disebabkan karena sebagai produk dan konstruksi manusia, ilmu-ilmu keislaman adalah historis karena lahir dari pemahaman manusia dalam batas-batas ruang dan waktu yang melingkupinya. Disamping itu, tidak ada sekat yang ketat yang memisahkan antara Islam historis dan Islam normatif, selama yang terakhir ini tidak diindetikkan dengan wahyu.

Pemetaan secara kasar tentang aplikasi pandang dan asumsi filsafat ilmu dalam bidangbidang kajian keislaman dapat dikemukakan sebagai berikut. Pertama, kajian al-Qur'an dapat menerapkan asumsi-asumsi filsafat hermeneutis, yang antara lain juga berkembang di sekolah Franfurt. Gadamer, penulis Truth and Method, yang memperkenalkan "peleburan dua batas cakrawala" (fusing horizon) antara pembaca dan pengarang, antara teks dan konteks, ${ }^{44}$ misalnya, sebagaimana yang diadopsi oleh Fazlur Rahman, dapat digunakan sebagai paradigma untuk kepentingan kontekstualisasi teks-teks al-Qur'an. Kedua, semua penelitian tentang Islam historis bisa melandaskan diri atas pendekatan-pendekatan yang asumsi filosofinya dijelaskan dalam filsafat ilmu. Ketiga, kajian tentang perbandingan agama agaknya mengharuskan diterapkannya landasan fenomenologisnya dalam filsafat ilmu.

Teologi Sebagai "Tlmu (Sains)": Penerapan Filsafat Ilmu Imre Lakatos dalam Kajian Agama. Di antara intelektual Barat dalam studi agama di satu sisi dan intelektual Barat yang bergumul dengan tradisi filsafat di sisi lain, adalah Nency Murphy yang tampaknya paling intens mencoba menerapkan beberapa paradigma filsafat ilmu kontemporer, terutama filsafat Imre Lakatos, dalam memahami doktrin-doktrin agama (Kristen Katolik). Dalam bukunya, Theology in the Age of Scientific Reasoning, ${ }^{45}$ Murphy menunjukkan penerapan "research program" Lakatos dalam dua tahap: (1) bahwa dalam deskripsi Lakatos tentang struktur teologi, ada sejumlah teori yang koheren yang sejajar dengan ketentuan formal program riset tersebut dan (2) bahwa kadang-kadang program riset teologi secara empiris adalah progresif.

Pada tahun 1965 Claude Welch menggunakan term "program" dalam pengertian Lakatosian untuk deskripsinya tentang sejarah teologi. Oleh karena itu, menurut Murphy, upaya Welch merupakan langkah awal penerapan program Lakatosian tersebut. Ia juga menemukan dalam teologi apa yang disebut Lakatos sebagai hard core (heuristik negatif dan heuristik positif). Nency Murphy dengan sangat mendalam membuktikan bisa diterapkannya program riset tersebut, terutama pada bagian 4 bukunya (The Modernist-Testing the Method), bagian 5 (Data for Theology) dan bagian 6 (Scientific Theology). Tulisan ini tidak memungkinkan untuk menjelaskan obsesi Murphy tersebut di sini.

${ }^{43}$ Abdullah, "A Preliminary Remark...", 4. Juga C. A van Peursen, Susunan Ilmu Pengetabuan: Sebuah Pengantar Filsafat Ilmu (Jakarta: Gramedia, 1985), h. 86.

${ }^{44}$ Lihat C. Verhaak dan R. Haryono Imam, "Pengantar", h. 176-177; T.K. Seung, Semiotics and Thematics in Hermeneutics (New York: Columbia University Press, 1982), h. 188. 1990), h. 86.

${ }^{45}$ Nency Murphy, Theology in the Age of Scientific Reasoning (Ithaca and London: Cornell University Press, 


\section{Simpulan}

Pertama, pengembangan IAIN masa depan harus memproyeksikan upaya aktualisasi filsafat ilmu dalam konteks peningkatan kualitas secara akademis dan keilmuan dengan mengintergrasikan filsafat ilmu ke dalam kurikulum program sarjana (S1) sebagai bagian yang integral dengan ilmu-ilmu keislaman lain. Dengan begitu, kerangka berpikir secara analitis, kritis, sintesis dan metodologis akan mengakar sejak dini dan melandasi berpikir secara akademis. Kedua, "krisis epistemologis" dan kurangnya pengetahuan tentang metodologi yang idealnya melandasi pada dataran asumsi-asumsi dasar secara filosofis kajian-kajian keislaman selama ini mengharuskan pengkajian asumsi-asumsi dasar keilmuan tersebut dan dijadikan dasar bagi kerja penelitian. Kajian Islam dalam fenomena sosial dan budaya, misalnya, harus dilandasi oleh pendekatan-pendekatan yang asumsi dasarnya telah mapan, semisal fenomenologi, hermeneutika, atau model positivistik. Ketiga, peningkatan kualitas kajian-kajian keislaman, yang tak hanya dalam fenomena sosial budaya, dapat dilakukan dengan meletakkan kajian tersebut dalam "kerangka" atau paradigma filsafat ilmu. Sebagai contoh aplikasinya, "program riset" (research program) Imre Lakatos sebagai filsafat ilmu yang berkembang di abad ke-20 telah dijadikan "kerangka" telaah teologis oleh Murphy.

\section{Daftar Pustaka}

Abdullah, M. Amin. 1992. The Idea of Universality of Ethical Norm in Ghazali and Kant, Turki: Turkiye Diyanet Vakfi.

1995. "Kata Pengantar", dalam Ilmu Pengetahuan dan Metodenya, ed. C.A. Qadir. Jakarta: Yayasan Obor Indonesia, 1995.

1996. Studi Agama: Normativitas atau Historitsitas?, Yogyakarta: Pustaka Pelajar.

1998. "A Preliminary Remarks on the Philosophy of Religious Science", dalam alJami'ab: Journal of Islamic Studies, Yogyakarta: IAIN Sunan Kalijaga, No. 61.

Arkoun, Mohmmed. 1994. Nalar Islam dan Nalar Modern: Berbagai Tantangan dan Jalan Baru, terj. Rahayu S. Hidayat, Jakarta: INIS.

Azra, Azyumardi. 1999. Pendidikan Islam: Tradisi dan Modernisasi Menuju Millenium Baru, Jakarta: Logos.

Beerling et. al. 1990. Inleiding tot de Wetenschapleer, terj. Soejono Soemargono, Yogyakarta: Tiara Wacana.

Bloom, Allan. 1987. The Closing of the American Mind: How Higher Education Has Failed Democracy and Impoverished the Shouls of Today's Students. New York: Simon and Schuster Inc.

Gallagher, Kenneth T. 1994. Epistemologi: Filsafat Pengetabuan, disadur oleh P. Hartono Hadi dari Philosophy of Knowledge, Yogyakarta: Pustaka Kanisius.

Habermas, Jurgen. 1996. The Philosophical Discourse of Modernity, transmigran. Feredrich Lawrence, Massachussetss: The MIT Press.

Hamlyn, D.W. 1967. "Epistemology, History of', dalam The Encyclopedia of Philosophy, ed. Paul Edwars, vol. 3.

Hanafi, Hasan. T.th. Al-Dîn wa al-Tsawrah. Mesir: Maktabat Madbûlî.

Kimbal, Roger. 1990. Tenured Radicals: How Politics Has Corrupted Our Higher Education. Chocago: Ivan R. Dee.

Leaman, Oliver. 1985. An Introduction to Medieval Islamic Philosophy. London dan Cambridge: Cambridge University Press.

Lubis, Nur Ahmad Fadil. 1998. "Perguruan Tinggi Agama Islam dalam Menyongsong Millenium Ketiga: Peluang dan Tantangan di Tengah Makin Berkiprahnya Perguruan Tinggi Asing di Indonesia", dalam Perguruan Tinggi Islam di Era Globalisasi, ed. Syahrin Harahap Yogyakarta: Tiara Wacana dan IAIN Sumatera Utara. 
Magnis-Suseno, Franz. 1992. Filsafat Sebagai Ilmu Kritis, Yogyakarta: Pustaka Filsafat/ Kanisius.

Mastuhu. 1999. Memberdayakan Sistem Pendidikan Islam, Jakarta: Logos.

Meuleman, Johan H. 1990. "IAIN di Persimpang Jalan", dalam PERTA: Jurnal Pendidikan Tinggi Islam, Jakarta: Departemen Agama RI.

Muhadjir, Noeng. 1998. Filsafat Ilmu: Telaah Sistematis, Fungsional, Komparatif, Yogyakarta: Penerbit Rake Sarasin.

Murphy, Nency. 1990. Theology in the age Scientific Reasoning, Ithaca dan London: Cornell University Press.

Pelikan, Jaroslav. 1990. The Idea of University: A Reeximination, New Haven, Yale University Press.

Rahman, Fazlur. 1982. Islam and Modernity: Transformation of an Intelectual Tradition, Chicago London: The University of Chicago Press.

Ravith, Diane. 1987. The Schools We Deserve: Reflections on the Educational Crises of Our Time. USA: Basic Books.

Reid, Donald Malcolm. 1955. "Al-Azhar", dalam The Oxford Encyclopedia of the Modern Islamic World, ed. John L. Esposito. Oxford: Oxford University Press.

Sober, Elliot. 1995. Core Questuons in Philosophy: A Text With Readings, New Jersey: Prentice Hall.

Strauss, Anslem dan Juliet Corbin. 1997. Basics of Qualitative Research: Groundes Theory Procedures and Technique, disadur oleh M. Djunaidi Ghony, Surabaya: Bina Ilmu.

Suhono, Anton. 1979. "Pendidikan dan Epistemologi", dalam AMW, Pranakarka dan Anton Bakker, Epistemologi Kebudayaan dan Pendidikan, Yogyakarta: Kelompok Studi Filsafat Yogyakarta.

Suriasumantri, Jujun S. 1984. Filsafat Ilmu: Sebuah Pengantar Populer, Jakarta: Sinar Harapan.

Sykes, J. B., (ed). 1979. The Concise Dicitonary, Oxford: The Clarendom Press.

The Liang Gie. 1998. Philosophy As An Element of Human Existence: A Systematic Clarification. Yogyakarta: PUBIB.

Tim Penyusun. 1998. Kurikulum dan Silabi LAIN Sunan Kalijaga Program Sarjana (S1). Yogyakarta: IAIN Sunan Kalijaga.

Toffler, Alvin. 1992. Future Shock, terj. Sri Koesdiyatinah, Jakarta: Pantja Simpati.

Van Ess, Josep. "The Logival Structure of Islamic Theology", dalam An Anthology of Islamic Studies, ed. Issa J. Boullata. Montreal: McGill and Indonesia IAIN Development Project.

Verhaak, C. dan R. Haryono Imam. 1997. Filsafat Ilmu Pengetabuan. Jakarta: Gramedia.

Watt, William Montgomery. 1992. Islamic Philosophy and Theology: An Extended Survey. Edinburgh: Edinburgh University Press.

Wilshire, Bruce. 1990. The Moral Collapse of the University: Professionalism, Purity, and Alienation. New York: Suny.

Ziolskwi, Theodore. 1990. "The Ph.D. Squid," dalam The American Scholar, Vol. 59, No. 2 : 177-195. 